\title{
COVID-19 and labour in agriculture: Economic and productive impacts in an agricultural area of the Mediterranean
}

\author{
Raffaele Cortignani, Giacomo Carulli, Gabriele Dono \\ Department of Agriculture and Forest Sciences (DAFNE), University of Tuscia, Viterbo, Italy
}

\begin{abstract}
Social distancing and mobility restrictions adopted in Italy to deal with the COVID-19 emergency can also alter the operating conditions of the Italian agricultural labour market. The restrictions can limit the movement of temporary labour that is already on the national territory and can prevent the arrival of other foreign workers to be engaged mainly in the harvesting of crops. In Italy, temporary workers support diverse farming activities and are mainly young immigrants engaged in working relationships characterized by extreme flexibility. They must be available for very
\end{abstract}

Correspondence: Gabriele Dono, Department of Agriculture and Forest Sciences (DAFNE), University of Tuscia, via San Camillo de Lellis, 01100 Viterbo, Italy.

Tel.: +39.0761357275 .

E-mail: dono@unitus.it

Key words: COVID-19; labour in agriculture; economic and productive impacts; agricultural area; Mediterranean.

Acknowledgements: The authors thank the anonymous referees, whose comments allowed to markedly improve the analysis.

Funding: the study is supported by the project Department of Excellence, funded by Ministry of Education, University and Research (http://www.unitus.it/it/dipartimento/dafne/eccellenza-nella-ricerca-enella-didattica/articolo/sintesi-del-progetto, Law 232/2016). The funder had no role in the study design, data collection and analysis, decision to publish, or manuscript preparation.

Contributions: The authors have common responsibility for this study, whose parts are the result of joint work and full sharing. However, Giacomo Carulli wrote the paragraphs Study area and technical-economic characteristics, Results; he also found the bibliography, the sitography and oversaw the references drafting. Raffaele Cortignani wrote Abstract, Economic Model, Simulated Scenarios, Discussion. Gabriele Dono wrote Introduction, The importance of immigrant labor to the agricultural economy, Conclusions.

Received for publication: 13 May 2020.

Revision received: 28 May 2020.

Accepted for publication: 5 June 2020.

(C) Copyright: the Author(s), 2020

Licensee PAGEPress, Italy

Italian Journal of Agronomy 2020; 15:1653

doi:10.4081/ija.2020.1653

This article is distributed under the terms of the Creative Commons Attribution Noncommercial License (by-nc 4.0) which permits any noncommercial use, distribution, and reproduction in any medium, provided the original author(s) and source are credited. different tasks, interacting with multiple farms and moving between different areas of the country, generally based on the succession of the harvesting calendars of the main crops. Reducing the mobility of this workforce on the national territory decreases its availability in local labour markets with worrying damage to agricultural production. This paper analyses the possible impact of this labour availability reduction in a farming area of Southern Italy (Centre-West Sardinia), where various farm types operate, with diverse productive orientations. An economic model estimates this impact on production and income based on the structural characteristics of these farm types, among others own farm labour endowment, as well as on the technical requirements of the productive processes, including labour needs. The model considers the expectations of farmers on the temporary labour availability and identifies the possible adaptations that can be undertaken to better contrast the reduction generated by the constraints to the mobility of individuals in the COVID-19 crisis. These adjustments result in changes in income levels, as well as employment in the single farm types and the area as a whole. There is a strong, albeit very diversified, impact on the types of farms. Significant reductions in income are found in the types that heavily depend on temporary labour for certain crop operations, especially harvesting. These effects are generated despite these farms change their activities, expanding some crops to make better use of their family labour and permanent employees. The less profitable types of farm, therefore even less able to attract external resources, considerably worsen their conditions; this would aggravate the social and environmental balance of the areas in which they operate, which are also the most marginal in the study area.

\section{Introduction}

The travel restrictions throughout the country due to the 19COVID crisis arouse many fears over different aspects. One of these is linked to the possibility of adequately satisfy the working needs of Italian agriculture, which in recent years has gradually increased the use of foreign workers. At present, the health emergency greatly limits the possibility of moving, both to foreign workers to the Italian territory, and to those who, already present in Italy, move among regions following the harvesting calendars of agricultural products. Various countries are attempting to respond to the reduction of worker's availability for their economy. Portugal regularized immigrants pending residence permits. Germany authorized 80 thousand seasonal workers to enter (40 thousand per month in May and June) despite the borders closure due to the pandemic. In this case the workers, generally coming from Eastern Europe, will travel in groups and only by airplane; also, health checks will be planned and foreign seasonal workers will be kept separate from others. Spain intends to address the lack of labour in agriculture by authorizing farms to temporarily hire up to 80,000 immigrants or unemployed until 30 June 2020. The 
Italian farmers' organizations, authorized by the Ministry of Labor, launched databases (Jobincountry for Coldiretti) to hire workforce on farms, and at May 22 the Agrijob platform (Confagricoltura) had collected 30,000 availability for farming work, mainly from unemployed people from the HoReCa. However, the problem appears to require more robust mechanisms to compensate for the contraction in the labour availability that could affect up to 300,000 seasonal foreign workers. In this regard, the Minister of Agriculture asks to temporarily regularize the workers already present in Italy in non-legal forms, while other politicians stress that the regularization should also concern the many other workers who may come to Italy in the coming weeks for the harvest seasons. Green corridors and dynamic quarantine for temporary workers from other nations were hence requested, and Confagricoltura obtained permission for two charter flights with 248 agricultural workers from Morocco. Other positions cite the International Monetary Fund forecasts of an Italian unemployment rate of $12.7 \%$, also due to the COVID lock-down, and ask for a farming employment of workers in sectors in crisis, such as tourism, of unemployed, including those who receive the citizenship income subsidy, students or even retirees. Finally, many pinpoint that the reform of the whole temporary labour market in agriculture should no longer be postponed, intervening on social security and also recruitment systems based on vouchers (Agricultura, 2020; ANSA Infomigrants, 2020; Corriere ortofrutticolo, 2020; Gambero Rosso, 2020; Ilsole24ore, 2020, RaiNews, 2020; Terra e Vita, 2020).

In this condition, it seemed to us of interest to evaluate the possible impact of a major restriction of manpower availability in agriculture. This emergency, and with this magnitude, is a completely new event for Italian agriculture and poses different problems from those that we generally evaluate, studying the alterations in the regimes of product prices and factors, or in the support and regulation policies of the sector. Italian agriculture is very varied and the workforce performs different functions with different types of relations with farms. Estimating the overall impact is therefore very difficult. Still, we thought that evaluating the possible different responses of farm types that differ in structural characteristics, production orientation and family labour availability could give interesting insights. In this attempt, we used a mathematical programming model that simulates the production choices of agriculture in the central-western part of the Oristano province, where different farm types operate, practicing both irrigated and rainfed agriculture (Dono et al., 2016). The model represents different types of these farms with different combinations of family and temporary labour: from small family-run units dedicated to more or less labour-intensive crops, to large farms that mainly employ temporary labour to grow orchards or to conduct cattle breeding at various levels of profitability and capital use. This structure, although not statistically representative of Italian agriculture, includes farm types that are very relevant for it.

The model simulates the production choices of these farms, and the use of temporary work, based on the working needs during the production cycle of their crops, as well as on farmers' expectation on that workforce availability. Specifically, a basic assumption of the model is that certain total labour availability can move in several months, for unskilled tasks, with extreme flexibility among the various farms at a given wage. This design of the temporary labour market in agriculture seemed to us quite coherent with the local reality studied in building the model. It also seemed consistent with the full flexibility in the use of temporary workers, mainly immigrants, described by the scientific literature on the subject. Based on this assumption, the model simulates how different expectations on the availability of this temporary labour induce farmers to adapt by changing the use of soil and, albeit partially, some structural features. In this regard, we apply various scenarios with progressive reductions of temporary labour availability expected by farmers when planning their activity.

The next paragraph contains various passages from the literature that describes the use of temporary labour in agriculture, as mentioned, based on extreme flexibility and availability for the most diverse and generally very tiring tasks, borne above all young workers. The following paragraph describes the model of irrigated and dry agriculture in the studied area, highlighting the variety of farm types and farming production activities that characterize it. Another paragraph defines the simulations of reduced labour mobility and the one after describes the results, highlighting the production and income impact, as well as the adaptations pursued by the various farm types. Finally, there are the discussion of results and some general conclusions.

\section{The importance of immigrant labour to the agricultural economy}

In the late eighties and early nineties, market globalization and creation of outsourced work chains in many parts of the world generated profound structural changes that notably changed the labour organization and performance conditions, boosting flexibility (Preibisch, 2010; Harrison and Lloyd, 2013; Bonanno, 2014; Bonanno and Cavalcanti, 2014). According to Bonanno (2014), labour flexibility provides for work time adaptability, up to discontinuity of use; labour activities flexibility, in which workers perform different tasks that require different skills; labour conditions flexibility and duration. Also, wages are increasingly determined by performance indicators, rather than by the time worked, emphasizing the importance of productivity. Finally, the ability to move between workplaces or mobility, is transformed into a key condition for employment and remuneration.

Various analyses of different international situations show how the management of migration flows has aimed to achieve the maximum with the flexibility of the labour force, also selecting them with attention to their productivity, to support the profitability conditions of the agricultural sector. This made it possible to manage recession situations by reducing employment and wages for immigrants: for example in California in 2008, hourly wages and bonuses for regularly hired workers increased, while the chances of receiving bonuses and wage increases reduced for most undocumented workers (Fan et al., 2015). Conversely, it made it possible to manage the recovery phase by significantly easing immigration restrictions: for example, since 2014 the absorption of Mexican workers has generated important advantages for US producers, allowing them to use major and elastic labour resources to reduce production costs (Marquez Alcalà, 2016). The use of migration labour force took place by making the best use of some of its important production peculiarities, such as the high labour productivity due to the low average age of workers which would seem difficult to emulate by local workers, generally older. Martin (2017) describes the efforts made by American farming producers who implemented the 4S strategy (Satisfy, Stretch, Substitute, Supplement) providing bonuses and health care to local workers, to overcome the demand contraction, replacing where possible migrant work with mechanization practices and only partially integrating labour shortages with temporary visas. In the first analysis, this strategy seemed to work; later, its limit emerged due to the high average age of American workers who, in their 40s, could hardly keep up with the rhythms of current production conditions. Moreover, according Zahniser et al (2018), the aging of the agri- 
cultural workforce is especially relevant to hired farm labour given the physicality of that work and the tendency of farmworkers to exit the sector as they get older. In any case, the study shows that the internal labour supply of the United States is rigid and that adopting mechanization is not always practicable and often occurs at the expense of product quality. Bonanno (2014) highlights that the use of migrant labour force in agriculture also dominates in the southern regions of the world: in Latin America migrant labour forces come both from neighbouring countries and other areas of the same country. Also in these situations, control of the workforce takes place through illegal migration processes or fixed-term immigration programs (Preibisch, 2012; Harrison and Lloyd, 2013).

Surveys and studies examined the use of immigrants in agriculture also in Italy. INEA (2014) found that a major part of foreign labour use is seasonal and follows the production cycles, carrying out activities of short duration, usually during harvest and transformation of main crops. Precariousness of employment relationships results, with many immigrants working less than 80 days a year, even if, working in animal husbandry and nursery gardening ensures greater production and employment continuity. Most migrants, especially in the South, are men, with an average age in the range of 20 to 40 years: this is a basic condition since employment concerns tasks requiring physical strength and prowess. In this regard, Sela (2016) highlights the labour supply features in Albania, where the average age of 31 years meets the labour market needs, especially in agriculture, where most of the young Albanians are occupied.

Corrado and Caruso (2015) point out that even in Mediterranean Europe, developments in the agro-food system generated a structural insufficiency of the family workforce and dependence on the hired labour force, which is now mainly migrant. The increased use of this workforce is based on the relegation processes of some groups and the return of others, Africans and Latin Americans to Spain; on feminization processes, as for strawberries or kiwis. These workers follow the seasons of agricultural harvesting to cope with the discontinuity of labour in other sectors of the economy. Migrant elements of work suffer the negative employment effects of the crisis more than the others. Statistics show that the unemployment rate for Italian workers in 2008-2013 doubled, from $6.4 \%$ to $12.5 \%$, while for immigrants residing in Italy passed from $8.5 \%$ to $17.7 \%$. In Spain, the unemployment rate increased from $8.9 \%$ to $25.1 \%$, while for immigrants it more than tripled, from $12.6 \%$ to $39.1 \%$. Thus, southern European agriculture benefits from a reserve army that follows the peaks in labour force requirements, in particular fruit and vegetables, whose production, above all the harvest, is structurally linked to flexible and low-cost migrant work. This set of workers, made up of non-EU and neo-EU migrants, helps to replace the indigenous workforce which, for example, in the southern Italian regions decreased by 84,234 units in 2008-2013, against the increase of 24,394 non-EU workers and 49,303 neo-EU workers. In Spain agricultural workers decreased from 905,800 in 2008 to 790,900 in 2013 , while the migrant component increased from $19.1 \%$ to $24 \%$ of the total workforce in agriculture.

INEA (2009; 2014) and CREA PB $(2017 ; 2019)$ analysed the evolution of the migrant component in farming labour, showing that this has gone from $19.4 \%$ in 2008 to $37 \%$ in 2013 , with notable leaps especially in the southern regions. Macrì et al. (2018) and CREA PB (2019) present these trends by examining the INPS data and obtaining that in Italy, in 2017, out of 1,059,998 agricultural workers employed, $34.2 \%$ (364,385 units) were immigrants and employed at $94.4 \%$ as temporary workers. Furthermore, farm- ing workers were 1,037,116 in 2008 and immigrants accounted for $25.9 \%, 91 \%$ employed as temporary workers. Mattioni and Tripodi (2018) show that in the 2007-2016 non-EU citizens have grown to almost double in the decade $(+88.3 \%)$, while EU immigrants have decreased until 2014, to rise again in the last two years. India and Pakistan generated the largest increases in the migratory flow, tripling their presence in Italian agriculture. Moreover, in 2016, more than half of non-EU agricultural workers came from India, Morocco and Albania. This expansion increased the incidence of males, representing in 2016 almost $2 / 3$ of the total, and contributed to keeping low the average workers' age.

According to the Ministry of Labor and Social Policies (MLPS, 2019) most of the farming workers are employed for less than 150 days and the employees have increased by about $10 \%$ for less than 50 days, for about 320 thousand workers in 2017. The employment contracts of Italian, Indian and Tunisian workers are longer - over 100 days per year - instead, the contracts of most workers from West Africa, Pakistan, Poland, Bulgaria and Romania last less than 50 days per year. On the other hand, workers employed in agriculture without any type of contract (hereinafter, irregular) would be $24.2 \%$ in 2018 and reach $34.9 \%$ among employees. Applying this rate to the total of employees in agriculture in 2018, around 470 thousand, irregular workers in Italy were estimated at around 164,000. Still, this estimate does not consider foreigners who are not residents or not registered.

According to CREA (2019) this condition has already emerged in the VI general census of agriculture which shows that 221,671 farms (13.4\% of the total) employ mainly unskilled labour in temporary activities and more strenuous tasks, and only $21 \%$ of their employees has permanent employment contracts. This happens above all in Trentino, Emilia Romagna and Puglia. Coderoni et al. (2018) show that most of the foreign workers are employed in large farms, in seasonal activities in permanent crops, arable crops and horticulture. Foreign workers are also employed in farms relying on extensive pastures, especially sheep in Sardinia, and on intensive farming, located in particular in the Po Valley.

All these elements depict an agricultural employment condition which also in Italy strongly trends towards labour flexibility and demands for the highest possible productivity. In this context, migrant labour is fundamental because it is characterized above all by the low average age workers, mainly temporarily employed and entering the labour market guaranteeing very high territorial mobility and adaptability in strenuous tasks and more varied shifts. Limiting these workers' mobility can thus reduce the possibility to perform many of the productive activities taking place in the Italian farming sector. We therefore used an economic mathematical programming model to analyse the possible impact of reducing the temporary labour availability in an agricultural area of southern Italy. This allowed detecting the possible effects on the income of farms in the area, as well as the impact on employment of their permanent labour units. The types of farm most affected by the limitation of mobility and the consequent reduction in the availability of work were also identified.

\section{Materials and methods}

\section{Study area and technical-economic characteristics}

The study area is a 54,000 ha farming district located in the central west area of Sardinia (Italy). The farming system was recon- 
structed using the data of the Italian $6^{\text {th }}$ General Agricultural Census, of the Farm Accountancy Data Network (FADN) and of a Water User Association (WUA) that supplies irrigation water from the Eleonora d'Arborea dam, with a reservoir of some 450 $\mathrm{Mm}^{3}$, of which $120 \mathrm{Mm}^{3}$ are made available annually to potentially irrigate 36,000 ha. The cropping systems are mainly based on cereals, especially durum wheat, barley, silage maize and rice, forage crops, such as alfalfa and Italian ryegrass, but also include horticultural crops such as artichokes, watermelon, tomatoes, citrus orchards, olive trees and vineyards. The breeding of dairy cattle in Sardinia is largely concentrated in this irrigated sub-zone (Arborea district), with a well-organized cooperative system for production, processing and marketing of cow milk. A rainfed subzone covers some 18,000 ha, where a limited amount of water is occasionally available, taken from wells in some farms. In this sub-zone, $55 \%$ of the agricultural land is made of pastures, tares, woods or set-aside fields; durum wheat and barley predominate the rest of the land. The dairy sheep industry is largely present in this sub-zone and involves some 372,000 sheep and several small sheep's milk processing plants.

The structural and economic characteristics of this agricultural system are embedded in a regional economic model composed of blocks that identify the area's representative farm types based on FADN data of that region. The farm types are specialist rice, citrus fruits, greenhouses vegetables, dairy cattle, sheep and mixed cropping. Additional analyses were carried out to subdivide specialist dairy cattle, sheep and mixed cropping farms into more homogeneous types based on structural, economic and managerial aspects. To this end, a hierarchical clustering method was first performed, which indicated the preferred number of groups among the FADN farms based on Euclidean square distances as average linkage index of selected features. Then, a k-mean method of non-hierarchical clustering was performed, to specify the internal composition of these groups by maximizing the internal similarity among farms. The clustering variables used are return on equity, gross margin over milk, illness score and reproductive capacity for the specialist dairying; return on equity, gross margin, percentage of arable land and irrigated area for mixed-cropping and specialist sheep.

The specialist FADN dairy cattle farms were divided into two groups with a better-performing group (Cattle A), which has more economically efficient feeding and a shorter calving interval compared to the Cattle $B$ group. Specialized FADN sheep farms were clustered into three groups (Sheep A, Sheep B, Sheep C), according to irrigation availability for forage production. The mixed cropping farms were divided into five groups according to cropping patterns, structural characteristics, and location (in the irrigated zone: Vegetables-Cereals, Cereals-Forages, Tree-arable crops; in the rainfed zone: Vegetables-Fruit, Cereals-Forages). Specialized farms in rice, citrus and greenhouse were also included in the irrigated area.

All thirteen farm types represent the average of the various characteristics within the FADN sample. Representativeness was ensured using the FADN database and other local sources to confirm accurate reflections of resource use and economic results in the study area. Each farm type was multiplied by the proportion of farms in the study area it was estimated to represent. The production conditions of crops and livestock in the area were specified based on interviews with farmers, agronomists and managers of the regional administration and local agricultural cooperatives. Labour, chemicals and water requirements are defined for the various crop production stages, as well as yields and prices. Likewise, the nutritional constraints for the various livestock categories reflect their different nutritional needs and are specified on the basis of the actual food rations and the products obtained. These requirements are met by the forage produced on the farm and by the purchase of feed on the market. Output and input prices are identified through the use of local databases and through interviews. The availability of land, labour and water was determined using the data of the 6th general Italian agricultural census of the Accounting Network of Agricultural Data (FADN) and of the WUA.

\section{Economic model}

The mathematical representation of the economic model can be compactly defined as follows:

$$
\begin{aligned}
& \max _{x_{1}^{L}, X_{n_{s}}^{R}, X^{A}} z=G I X_{1}^{L}+V E N E-\sum_{n=2}^{N} \sum_{s=1}^{S} P r_{s} \operatorname{Cr} X_{n_{s}}^{R}+P m Q m \\
& \text { subject to } \\
& G I=P Y+S-C \\
& Q m=Y m X^{A} \\
& A X_{1}^{L} \leq B \\
& A_{s} X_{1}^{L} \leq B+\sum_{n=2}^{N} X_{n_{s}}^{R} \forall s \\
& F Y_{s} X_{1}^{L}+\sum_{n=2}^{N} X_{n_{s}}^{R} \geq R X^{A} \forall s \\
& X_{1}^{L} \geq 0 \text { and } X^{A} \geq 0 \\
& X_{n_{s}}^{R} \geq 0 \forall s
\end{aligned}
$$

The mathematical formulation uses matrix notation with explicit definition of the sets that characterize the Discrete Stochastic Programming model (Dono et al, 2016; Cortignani and Dono, 2018): stages $(n)$ and states of nature $(s)$. Three types of variables $(X)$ are considered: the first refers to the land allocation (superscript $L$ ), the second refers to the additional resources (superscript $R$ ) and the last refers to the animal number (superscript $A$ ).

In more detail, $X_{1}^{L}$ refer to the land allocation of which occurs in the first stage, and $X_{n_{s}}^{R}$ are the corrective actions performed in the subsequent states $(n=2, \ldots, N)$ on the actual occurrence of one of the states $(s)$. These actions modify some available resources, i.e., water and feeds, by water pumping and purchase of feeds and fodder, determining a cost $(\mathrm{Cr})$ to the farms. Equation (1) is the objective function $(z)$ that sums different components: gross income $(G I)$ of the activities chosen in the first stage $\left(X_{1}\right)$, number $(N E)$ and unit value $(V E)$ of entitlements related to the Single Payment Scheme of the CAP ante-2014 (decoupled payments) and costs $(C r)$ of the corrective actions $X R_{n s}$. In this latter case, the values of the uncertain activities in the states of nature are weighted with their probabilities $\left(\operatorname{Pr}_{s}\right)$ and summed over $N$ stages. Finally, the objective function sums the revenues of milk, based on the price $(P m)$ and the total quantity $(\mathrm{Qm})$. Equation (2) defines the gross income of the cropping activities, where $P$ are the output prices, $Y$ are the yields, $S$ are CAP coupled payments and $C$ are the unitary costs per hectare related to production costs (seeds, fertilizers, herbicides, etc.). Equation (3) defines the milk total quantity $(\mathrm{Qm})$, where $Y m$ is the milk unitary production and the $X^{A}$ variables refer to animal number. Constraints (4) refer to land and labour resources: $A$ is the matrix of technical constraints, and $B$ is the quantity of available resources. Constraints (5) refer to the 
water resource and show that uncertainty affects $A_{s}$, i.e., watering needs of irrigated crops, and that choices involve corrective actions, $X_{n_{s}}^{R}$, in stages $(n)$ for each state $(s)$. Constraints (6) refer to animal feeding: $F$ are the unitary contributions of nutritional elements of the forage crops, and $R$ are the unitary nutritional needs of livestock categories. The uncertainty affects $Y_{s}$, i.e., yields of forage crops and that choices involve corrective actions, $X_{n_{s}}{ }^{R}$, in stages $(n)$ for each state $(s)$. The cropping activities were calibrated to the reference year (2010) with the PMP approach of Röhm and Dabbert (2003) that allows modelling the choices between technically similar crops whose mutual substitution elasticity is greater than that relating to other crops. The calibration involved deciding land allocation among crops in the first stage (Dono et al., 2016; Cortignani and Dono, 2018).

With regard to labour, the requirements, the availability of the farm and the use of extra-farm labour are defined by farm type and time period (10 days); extra-farm labour availability is defined at time period and at global area levels. This means that extra-farm labour is considered a common resource that can be used and exchanged among farms. In order to maximize income, the model allocates this scarce common resource to activities (and farms) with higher productivity. Based on this objective, the model first removes the less productive activities when this labour availability is reduced, as in the scenarios that will be described in the next paragraph.

In more detail, the model represents agricultural labour and its use in the area considering that approximately $83 \%$ of it is provided by family members and permanent employees, while extra-farm labour is used mainly in some stages of production (such as pruning and collection). These phases last very little (10-15 days) and absorb a lot of manpower, therefore, in case of strong reduction of the extra-farm labour availability, only a small part can be replaced by family labour and permanent workers. The ability to accomplish this replacement can increase by practicing other crops that require labour in other periods. The model allows this replacement also in the case of tree crops by providing that, in addition to not harvesting some surfaces, farmers may not renew a part of the tree plants that are at the end of the production cycle and practice other crops in their place.

\section{Simulated scenarios}

In the simulation phase, various scenarios were considered in terms of reduction of temporary hired labour availability and the increase of feed prices (Table 1). As regards extra-farm labour, two time periods were identified. The first refers to March-October, the period of greatest external-farm labour needs, when sowing of the spring-summer crops, pruning of the tree crops, and harvesting of a large part of crops occur. This period was also chosen because the blocking period due to the COVID-19 crisis began in March. The other period is November-February, when agricultural labour needs are lower and there is also less competition with other economic sectors (e.g. tourism). All these aspects were considered in simulating different percentage reductions, as shown in Table 1: from $50 \%$ to $90 \%$ in March-October, $50 \%$ in November-February. Basically, we assume that at least $50 \%$ of the temporary workers used in the periods of lower working needs live in the municipalities where the farms are located. Therefore, in those periods, the restrictions on mobility among municipalities and Regions subtract the remaining $50 \%$ of that labour. Then, we simulate greater impact scenarios in periods when the labour needs increase and temporary itinerant workers are necessarily involved. In those periods the mobility restrictions have larger impacts that we simulate up to $90 \%$.

Other effects of the COVID-19 crisis may amplify the impact of lower temporary labour availability, including many price changes which are generally worsening market conditions in the agricultural sector. Considering all these changes simultaneously seemed inappropriate and we focused on only one of them, namely the possible increase in feed prices. Various reasons made it interesting. Firstly, because possibly reinforced by a lower forage production due to the same lack of temporary work, used in the forage harvesting as unskilled support, yet difficult to replace with other farm workers fully engaged in other qualified tasks. Secondly, because cattle and sheep farms are very important in the area in terms of income and land extension: cattle farms produce $59 \%$ of the area income, while sheep farms manage 37\% total land, especially in the non-irrigated sub-area (88\%). Moreover, the structural and managerial features of the area's cattle and sheep farms also represent other analogous productive Italian areas: hence, their reaction to the new scenarios can be indicative also for other territories. Finally, because the ISMEA data on forage prices in the last two March and April, showed greater variability and increases over the past years (2019-2017) and the increase could be greater in situations of labour scarcity in the farms (ISMEA, 2020).

\section{Results}

A first result concerns the employment condition in the baseline, Table 2, from which differences between the 13 farm types emerge. The first differences concern the availability and use of the permanent farm labour units (LU), defined as the sum of family and wage labour contracted with stable employment contracts, where LU are obtained by dividing by 2200 the total hours provided by each labour category on each farm type. Comparing the available and employed farm labour units shows that only livestock farms employ a high share of the former, due to the working continuity that characterizes the livestock breeding activities. All the other types employ less than $65 \%$ of the farm workforce, down to $18 \%$ in the small extensive Vegetables - Fruit farm in the nonirrigated area. Other differences concern the use of temporary labour, with its percentage weight on total employed labour, and the number of temporary labour units employed in the area. This kind of labour notably satisfies farm labour needs in Rice and in

Table 1. Simulated scenarios of percentage (\%) extra labour reduction and feed prices increase.

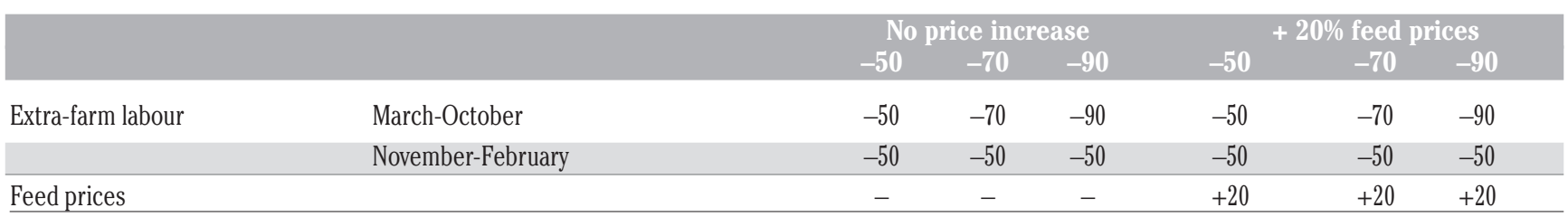


Citrus farm types (more than 50\%), which are also capable of occupying almost a full unit of temporary labour. The other types, despite the economic size of some of them, occupy less than one unit of this labour per farm. Therefore, $73 \%$ of the total use of temporary labour in the area is necessarily occupied by interacting with multiple farms; or, in other words, only $6 \%$ of the farms in the area (i.e. rice and citrus from Table 2: number of farms) can absorb an entire temporary labour unit. In any case, absorbing a LU does not mean continuously employing a worker throughout the year. The employment, in fact, relates to short periods, usually for harvesting, and the LUs of this and following tables are obtained by adding up the labour provided by several workers in the same period. Let us now examine the simulation results on social, productive and economic aspects at area level (Table 3) and per farm type (Tables 4-6). Table 3 shows the initial situation (baseline) in the area and the impacts of the reduced availability of temporary labour on land use for tree and herbaceous crops (reused and sold), on feed purchases, on the number of bred cattle and sheep, on use of farm labour, on the farm net income. The first three columns report the results of reductions in the only available temporary labour. The $50 \%$ drop causes farms to reorganise their activities by noticeably reducing tree crops and, albeit less, herbaceous crops for sale; greater restrictions on this labour in March-October penalize herbaceous crops more, to the relative benefit of trees. There is also a drop in fodder crop production and a marked increase of feed purchases; both these variations accentuate with further drops of available temporary labour. The feed purchases raise allows keeping unchanged the size of cattle and sheep breeding. Still, reducing the cultivation of herbaceous crops and trees also reduces the employment of stable farm labour and area's farming income.

The other three columns of Table 3 show the impact of associating a $20 \%$ raise in the feed price to the availability decrease of temporary labour. As mentioned, ISMEA already provides signs of fodder prices increases; furthermore, changes in those prices have been observed in the past in response to reductions in farms production. This increase generates devastating impacts on the activities and income of many livestock farms already at $-50 \%$ of temporary labour. Under this condition, sheep farms try to increase fodder self-production, but, with the new feed prices and less temporary labour available, they are unable to maintain the activity level and have to reduce the size of the flocks. The activity level fall also reduces farm labour use, as well as farming income. Note that the number of cattle heads only declines when temporary labour availability decreases $90 \%$ in March-October.

Table 2. Farm types - labour units (LU): available and employed permanent farm labour, employed temporary labour and its percentage on total employment; area's temporary employed LU per farm type.

\begin{tabular}{|c|c|c|c|c|c|c|c|}
\hline & $\begin{array}{c}\text { Number of } \\
\text { farms represented }\end{array}$ & $\begin{array}{l}\text { Farm net } \\
\text { income }(e)\end{array}$ & $\begin{array}{l}\text { Perma } \\
\text { Available }\end{array}$ & $\begin{array}{l}\text { farm LU } \\
\text { Employed }\end{array}$ & $\begin{array}{c}\text { Employed } \\
\text { temporary LU } \\
\text { per farm }\end{array}$ & $\begin{array}{c}\text { Temporary as } \\
\% \text { of total } \\
\text { employed LU }\end{array}$ & $\begin{array}{c}\text { Employed } \\
\text { temporary LL } \\
\text { in the area }\end{array}$ \\
\hline Rice & 24 & 198,231 & 2.00 & 0.85 & 0.93 & 52.4 & 22.3 \\
\hline Citrus & 68 & 42,866 & 1.70 & 0.56 & 1.10 & 66.3 & 75.1 \\
\hline Cattle A & 130 & 205,678 & 4.40 & 4.23 & 0.19 & 4.3 & 24.8 \\
\hline Cattle B & 40 & 163,484 & 6.30 & 4.28 & 0.23 & 5.1 & 9.2 \\
\hline Greenhouse & 46 & 26,285 & 3.50 & 1.03 & 0.00 & 0.3 & 0.1 \\
\hline Vegetables - Cereals & 562 & 33,126 & 1.70 & 1.06 & 0.26 & 19.6 & 146.1 \\
\hline Cereals - Forages & 55 & 75,735 & 1.20 & 0.66 & 0.43 & 39.4 & 23.6 \\
\hline Tree and arable crops & 100 & 10,886 & 2.00 & 0.52 & 0.01 & 1.8 & 1.0 \\
\hline Vegetables - Fruit & 100 & 10,268 & 1.70 & 0.31 & 0.00 & 0.0 & 0.0 \\
\hline Cereals - Forages & 94 & 28,333 & 1.20 & 0.54 & 0.20 & 27.1 & 19.0 \\
\hline Sheep A & 45 & 51,736 & 2.10 & 1.85 & 0.20 & 9.6 & 8.8 \\
\hline Sheep B & 188 & 9384 & 1.50 & 1.23 & 0.03 & 2.5 & 5.8 \\
\hline Sheep C & 129 & 24,657 & 1.60 & 1.50 & 0.16 & 9.7 & 20.7 \\
\hline
\end{tabular}

Table 3. Economic, social and productive indicators: baseline (absolute values) and simulated scenarios (percentage changes over baseline) without and with feed prices increase.

\begin{tabular}{lccccccc} 
& Baseline & \multicolumn{3}{c}{ No price increase } & \multicolumn{3}{c}{$+20 \%$ feed prices } \\
& & -50 & -70 & -90 & -50 & -70 & -90 \\
Extra-farm labour (h) & 784,509 & -50.0 & -62.4 & -74.9 & -50.0 & -62.4 & -74.9 \\
Tree crops (ha) & 1712 & -21.3 & -18.8 & -15.6 & -20.9 & -18.0 & -15.8 \\
\hline Herbaceous crops (ha) & & & & & & \\
$\quad$ Sold & 19,628 & -12.5 & -15.5 & -25.0 & -17.6 & -20.6 & -24.4 \\
$\quad$ Reused & 33,081 & -9.5 & -13.5 & -17.0 & -9.1 & -10.2 & -12.9 \\
Feeds purchased (tons) & 1237 & 20.7 & 28.7 & 30.6 & -12.6 & -7.9 & 7.9 \\
\hline Head of cattle $\left(\mathrm{n}^{\circ}\right)$ & 45,336 & 0.0 & 0.0 & 0.0 & 0.0 & 0.0 & -1.7 \\
Head of sheep $\left(\mathrm{n}^{\circ}\right)$ & 126,810 & 0.0 & 0.0 & 0.0 & -28.2 & -31.1 & -31.7 \\
\hline Farm labour $(\mathrm{h})$ & $3,845,131$ & -2.9 & -4.6 & -6.9 & -5.6 & -7.9 & -9.5 \\
Net income $(€)$ & $76,993,185$ & -3.1 & -5.9 & -12.0 & -11.4 & -15.0 & -22.0 \\
\hline
\end{tabular}


These data show different impacts on the various farms that we can examine with the data in Tables 4 and 5, i.e. examining the reduction of temporary and stable farm labour in the 13 farm types. Table 4 shows the different reduction, with some farm types immediately reducing the use of temporary labour by more than $50 \%$ of the simulated availability drop: the greatest absolute impacts occur in Citrus and Cereals - Forages, which employ significant quantities of this labour. The progressive decrease in general availability is reflected with similar trends on the various farm types. It is also interesting to note that dairy cattle farms respond to higher feed prices by increasing their use of temporary labour. To this end, they increase the cultivation of shorter-cycle maize at the expense of the longer cycle and, in this way, they also increase the cultivation of ryegrass. To a lesser extent, these crops, as well as triticale, also expand at the expense of alfalfa and clover. In addition, minor horticultural crops are eliminated. This generates competition with the other types for the use of temporary labour, which dairy cattle farms increase at the expense of the others. With the extreme reduction in the availability of temporary labour, dairy cattle farms no longer increase its use and also eliminate heads of dairy cows. Tree and arable crops run counter to the others. However, this type of farm absorbs negligible quantities of temporary labour and does not affect the general results of its lesser availability.

Table 5 shows that this variation entails a modification of the entire production organization of the farms which reduces their level of global activity, also reducing the use of farm labour. In some cases this reduction is dramatic and, for example, in sheep farms the increase in fodder prices generates a sharp reduction in farm employment, together with the reduction in livestock, described in Table 3. Conversely, it is interesting the case of the Citrus farms that, in response to reduced expectations of temporary labour availability, reorganize their activity increasing the use of family labour. This occurs despite the drop in fruit production shown in Table 3, to which this type contributes by reducing the citrus fruits production and increasing herbaceous crops such as to better exploit the availability of stable farm labour. In contrast,

Table 4. Farm types: temporary units of labour in the baseline (absolute values) and in simulated scenarios (percentage changes over baseline) without and with feed prices increase.

\begin{tabular}{lccccccc} 
& Baseline & \multicolumn{3}{c}{ No price increase } & \multicolumn{3}{c}{$+20 \%$ feed prices } \\
& & -50 & -70 & -90 & -50 & -90 \\
Rice & 0.93 & -3.6 & -23.5 & -88.0 & -10.5 & -31.5 & -83.7 \\
Citrus & 1.10 & -52.4 & -63.7 & -64.5 & -55.6 & -63.1 & -64.5 \\
\hline Cattle A & 0.19 & -28.7 & -31.4 & -41.5 & 4.0 & 1.1 & -44.8 \\
Cattle B & 0.23 & -3.0 & -25.8 & -43.4 & 5.1 & -2.7 & -43.4 \\
\hline Greenhouse & 0.00 & -80.9 & -84.5 & -100.0 & -82.0 & -88.0 & -100.0 \\
Vegetables - Cereals & 0.26 & -54.8 & -68.3 & -81.1 & -57.9 & -74.3 & -81.2 \\
\hline Cereals - Forages & 0.43 & -69.1 & -74.6 & -83.0 & -68.7 & -75.3 & -82.7 \\
Tree and arable crops & 0.01 & -25.4 & -17.2 & -9.5 & -22.8 & -16.4 & -9.7 \\
\hline Vegetables - Fruit & 0.00 & 0.0 & 0.0 & 0.0 & 0.0 & 0.0 & 0.0 \\
Cereals - Forages & 0.20 & -48.4 & -53.1 & -64.6 & -54.1 & -52.7 & -64.8 \\
\hline Sheep A & 0.20 & -67.8 & -98.2 & -98.4 & -73.9 & -97.9 & -98.4 \\
Sheep B & 0.03 & -68.6 & -80.3 & -96.4 & -68.5 & -79.1 & -96.4 \\
\hline Sheep C & 0.16 & -71.9 & -88.5 & -95.7 & -66.5 & -88.8
\end{tabular}

Table 5. Farm types: stable units of labour in the baseline (absolute values) and in simulated scenarios (percentage changes over baseline) without and with feed prices increase.

\begin{tabular}{lccccccc} 
& Baseline & \multicolumn{3}{c}{ No price increase } & \multicolumn{3}{c}{$+20 \%$ feed prices } \\
& & -50 & -70 & -90 & -50 & -90 \\
Rice & 0.85 & -3.1 & -1.8 & -20.6 & -2.5 & -2.2 & -17.4 \\
Citrus & 0.56 & 17.5 & 16.2 & 16.3 & 17.4 & 16.7 & 16.2 \\
\hline Cattle A & 4.23 & 1.2 & 1.3 & 1.6 & -0.5 & -0.3 & -0.6 \\
Cattle B & 4.28 & 0.0 & 1.0 & 0.6 & -0.5 & -0.1 & 0.6 \\
\hline Greenhouse & 1.03 & -0.2 & -0.1 & -0.2 & -0.2 & -0.1 & -0.2 \\
Vegetables - Cereals & 1.06 & -9.1 & -14.1 & -19.5 & -10.3 & -16.1 & -19.5 \\
\hline Cereals - Forages & 0.66 & -8.0 & -8.7 & -11.7 & -8.0 & -8.8 & -11.5 \\
Tree and arable crops & 0.52 & -2.2 & -1.4 & -0.7 & -2.0 & -1.4 & -0.7 \\
\hline Vegetables - Fruit & 0.31 & 0.0 & 0.0 & 0.0 & 0.0 & 0.0 & 0.0 \\
Cereals - Forages & 0.54 & -4.6 & -5.2 & -9.0 & -5.1 & -5.2 & -9.0 \\
\hline Sheep A & 1.85 & -0.9 & -6.2 & -6.6 & -49.5 & -61.9 & -63.3 \\
Sheep B & 1.23 & -0.5 & -3.0 & -4.3 & -25.7 & -25.7 & -27.0 \\
\hline Sheep C & 1.50 & -0.4 & -2.2 & -4.1 & -13.4 & -13.9
\end{tabular}


Cattle farms, Greenhouses, Tree and arable crops show very small variations in farm labour use, confirming organizations that employ labour on a permanent basis.

Table 6 shows the percentage change in net income over baseline in the 13 farm types. Note that the impact is always very different between types and that already in the simulation without increasing fodder prices, there are significant reductions in income for the Citrus type and the farms that grow vegetables and herbaceous crops. These impacts increase greatly with the reduction in temporary labour availability. Significant negative impacts also occur in sheep farms; however, sharp income reductions of the latter take place when reductions of labour availability and feed crop price increase act together. As seen above, dairy cattle farms respond to this scenario by producing more on-farm fodder and, to this end, by absorbing more temporary labour from the local market. This occurs at the expense of the other types, which suffer a net income reduction even at $50 \%$ decrease of temporary labour availability. Above that level income declines also affect cattle farms, though to a lesser extent than sheep due to the higher share of farm forages and higher capability of farm labour to compensate for the temporary labour reduction.

\section{Discussion}

The study area contains various aspects of interest on the possible impacts of the COVID-19 crisis on the labour use and income of Italian agriculture. Some of its farm types use mainly temporary labour (Citrus) or at least in the same amount of farm stable labour (Rice, Cereals - forages). In many farm types, part of the permanent farm labour is also provided by immigrants, which this study considers as stably available on the territory and used on the farm. The use of temporary labour presents a notable instability in working relationships since it is employed only in some, generally short, periods of the production cycle. In those periods more workers are involved and it is the sum of the hours worked by each of them to amount to the use of a complete unit. Consequently, many more workers are involved than the labour units calculated by adding the uses of the model. In particular, most of the employ- ment of farming temporary labour is for harvesting and lasts about one month. Thus, given that some crop cycles are integrated, it can be estimated that temporary workers involved in the area are even more than three times the 365 full labour units indicated by the model. On the other hand, a refined temporary labour allocation system is required, since workers must interact and move among multiple farms to achieve a decent annual income or employment benefits. For instance, unemployment benefit is obtained with 101 annual labour days that many temporary workers can only achieve by working on multiple farms, as their involvement is often limited to harvesting and generally for short periods on the average farm. This feature seems consistent with the temporary labour system in which many workers, generally immigrants, move on the national territory with the seasons of agricultural harvest, therefore, interact with multiple farms, as illustrated by Bonanno (2014) and by Coderoni et al. (2018).

The analysis revealed that some farm types will suffer important income effects even in the hypothesis that the restrictions to mobility among municipalities and regions reduces by only $50 \%$ the expectation of temporary labour availability. The net income reduction affects different farm types and ranges from 4, to 7, up to $14 \%$ for Citrus, which is the fruit farm that most uses temporary labour in the area. It is interesting to note that the simulations indicate that Citrus farms reorganize their productive activity by increasing the use of available family labour: yet, this does not balance the income reductions due to the abandonment of part of the citrus production.

The situation is aggravated if the effects of the expected restrictions on the movement of temporary labour overlap with possible market consequences of this lower availability. We have not considered changes in product prices due to sectorial consumer demand crises, such as those that affected the HoReCa sector. We have instead noted that in that area the lower availability of temporary workers could generate an appreciable reduction in the production of fodder. In our model the latter is highly mechanized and managed by expert family members or permanent workers; yet, also temporary workers are involved with unskilled support functions. Reducing or eliminating the latter requires reducing fodder cultivation because the qualified workers are fully engaged in other farm activities, such as the management of flocks or herds.

Table 6. Farm types: net income in the baseline (absolute values $€$ ) and in simulated scenarios (percentage changes over baseline) without and with feed prices increase.

\begin{tabular}{|c|c|c|c|c|c|c|c|}
\hline & Baseline & & ice inc & & & feed & \\
\hline & & -50 & -70 & -90 & -50 & -70 & -90 \\
\hline Rice & 198,231 & -0.3 & -4.6 & -39.0 & -1.4 & -7.0 & -34.7 \\
\hline Citrus & 42,866 & -14.4 & -23.4 & -25.9 & -16.8 & -23.1 & -25.9 \\
\hline Cattle A & 205,678 & -0.7 & -0.8 & -2.2 & -11.7 & -11.9 & -17.8 \\
\hline Cattle B & 163,484 & -0.1 & -1.5 & -4.8 & -10.6 & -11.2 & -19.4 \\
\hline Greenhouse & 26,285 & -0.1 & -0.1 & -0.2 & -0.1 & -0.1 & -0.2 \\
\hline Vegetables - Cereals & 33,126 & -5.2 & -11.5 & -21.7 & -6.2 & -14.8 & -21.7 \\
\hline Cereals - Forages & 75,735 & -7.9 & -9.0 & -12.1 & -7.9 & -9.2 & -12.0 \\
\hline Tree and arable crops & 10,886 & -0.2 & -0.1 & 0.0 & -0.2 & -0.1 & 0.0 \\
\hline Vegetables - Fruit & 10,268 & 0.0 & 0.0 & 0.0 & 0.0 & 0.0 & 0.0 \\
\hline Cereals - Forages & 28,333 & -4.2 & -5.4 & -12.8 & -5.5 & -5.3 & -12.8 \\
\hline Sheep A & 51,736 & -3.2 & -8.6 & -8.8 & -43.9 & -56.4 & -57.5 \\
\hline Sheep B & 9,384 & -4.2 & -6.7 & -10.6 & -45.4 & -48.0 & -54.1 \\
\hline Sheep C & 24,657 & -7.2 & -11.0 & -14.7 & -29.5 & -36.9 & -42.0 \\
\hline
\end{tabular}


We hypothesized that the reduction of forage production on farms could help increase the demand and prices of this product and all feed, further reinforcing trends observed in March and April 2020. Superimposing the increase in fodder prices to the expectation of lower labour availability has immediate devastating net income impacts that greatly affect sheep farms that were already in great difficulty before the COVID-19 crisis. These farms reduce the number of bred sheep, i.e. some of them already disappear with expectations of $50 \%$ restrictions on temporary labour availability. It is useful to remember that these farms, though representing a small share of the area's income, manage a considerable part of that zone, mainly in marginal and difficult territories (Dono et al., 2016). Their crisis, which appears devastating, could aggravate the abandonment phenomena that already afflict very fragile territories from a social and environmental point of view.

Finally, it is interesting to note that competitions among farm types are established in the area for the use of the available temporary labour. Dairy cattle farms respond to the increase in fodder prices by increasing the self-production of these feeds. In this way, they increase their competition for scarce temporary labour with other local farms types, which undergo a further contraction in their use of this labour resource, as in the case of Citrus. Expectations of more severe restrictions on the temporary labour availability generalize the crisis to the point that even dairy cattle farms reduce the number of raised cows.

\section{Conclusions}

Studying the scientific literature on temporary labour in agriculture and following the debate of today suggested us that this issue is always examined under the stimulus of extreme situations: hells of the slums where many of these itinerant workers live on our national territory; wage exploitation; forms to contrast COVID-19 which are annihilating prerequisites for relations of civilization, including the same mobility and freedom. In our current situation, several of these conditions overlap, which leads to debate on how balancing the mobility restrictions to avoid losing the provisions of over 300 thousand workers deemed necessary for the imminent harvesting campaigns.

Our simulations do not pretend to outline the set of problems posed to the management of this labour by the lock-down of the COVID-19. Still, our model includes farm types which are relevant for Italian agriculture, though not statistically representative, and it is interesting to study their possible reactions. Our results show that the types that use temporary labour in fruit and vegetable crops harvesting can suffer strong and direct productive impact due to its availability decrease; however, direct effects may also occur in farms that use this labour as unskilled support in some temporary activities of livestock breeding. Clearly, other effects of the COVID-19 crisis may amplify the impact of the reduced availability of temporary work and we have focused on the possibility that a decline in forage production will increase its prices. Such an effect could generate appreciable impacts also on farms which, at least in principle, could be considered less affected by our crisis, since they are mainly based on the use of permanent farm work. In particular, significant reductions in income may affect agricultural sectors which were already very weakened by the economic crisis of recent years. In the area we have studied, and in many other parts of Italy, these sectors preserve the environmental and social balance in the most marginal areas and their further deterioration would have very high costs.
Despite all their limitations, our results confirm the urgency of making the constraints to mobility required by the Italian antiCOVID 19 measures compatible, to the extreme flexibility required in this labour market, as well as to its considerable fragmentation. The latter implies that in many cases the work performance required for temporary work by individual farms concerns very limited periods, so these workers must necessarily interact with multiple farms to obtain a minimum monthly income. On the other hand, flexibility manifests itself by moving people across the national territory and by using labour allocation mechanisms that often do not express themselves in legally acceptable forms and which, however, so far no one has been able to reform.

The most general question to ask about these issues is how acceptable it is that modern society is based on the extreme instability of work and human relations, with evident grey areas in its running mechanisms. Our simulations could not give an answer on these issues. However, they help us to wonder if a production system that is in great need of these workers can still accept the extreme weakness of its systems of job placement and of social wage. The latter, in particular, should have low-cost housing for workers, more widespread and effective educational and health facilities, as well as decent collective mobility compatible with the environment.

\section{Highlights}

The measures taken in Italy to deal with the COVID-19 emergency modify the conditions of the agricultural labour market restricting the mobility of temporary labour.

Temporary workers support many farming activities in Italy and are mainly young immigrants engaged in working relationships characterized by extreme flexibility.

An economic model estimates the possible impacts of this labour availability reduction in a farming Mediterranean area of Southern Italy, where different farm types operate.

The farm types that heavily depend on temporary labour for certain crop operations, especially harvesting, face appreciable income level reductions.

Farm types with lower profitability are also notably endangered, with serious implications for the social and environmental balances of the marginal areas in which they operate.

\section{References}

Agricultura, 2020. Available from: https://www.agricultura.it/ 2020/04/20/coronavirus-dorfmann-e-de-castro-quarantenaattiva-per-lavoratori-agricoli-ue/

Bonanno A, 2014. La questione del lavoro nel settore agro-alimentare: questioni teoriche e problemi storico. Agriregionieuropa anno 10 n³6, Mar 2014.

Bonanno A, Cavalcanti JSB, 2014. Labor Relations in Globalized Food. Emerald, Publishing Bingley, UK.

Caruso F, Corrado A, 2015. Migrazioni e lavoro agricolo: un confronto tra Italia e Spagna in tempi di crisi, in "Tempo di cambiare", Rapporto 2015 sulle migrazioni interne in Italia, A cura di Colucci M. e Gallo Stefano. Donizelli Editore, Roma, Italy.

Coderoni S, Macrì MC, Cardillo C, Perito MA, 2018. Farms Employing Foreign Workers in Italy. An Analysis with Census Micro Data. German J. Agric. Econ. 67.

Consiglio per la ricerca in agricoltura e l'analisi dell'economia agraria CREA, 2019. Annuario dell'agricoltura Italiana 2017, Roma, Italy. 
Consiglio per la ricerca in agricoltura e l'analisi dell'economia agraria CREA, 2019. Il contributo dei lavoratori stranieri nell'agricoltura italiana, a cura di Macrì M.C., Roma, Italy.

Corriere ortofrutticolo, 2020. Available from: http://www.corriereortofrutticolo.it/2020/03/26/coronavirus-leuropa-senza-unmilione-lavoratori-agricoli-stagionali/

Cortignani R, Dono G, 2018. Agricultural policy and climate change: An integrated assessment of the impacts on an agricultural area of Southern Italy. Environ. Sci. Policy 81:26-35.

Dono G, Cortignani R, Dell'Unto D, Deligios P, Doro L, Lacetera N, Mula L, Pasqui M, Quaresima S, Vitali A, Roggero PP, 2016. Winners and losers from climate change in agriculture: Insights from a case study in the Mediterranean basin. Agric. Syst. 146:65-75.

Fan M, Pena AA, Perloff JM, 2015. Effects of the Great Recession on the U.S. Agricultural Labor Market. IRLE Working Paper N 104-15.

Harrison J, Lloyd S, 2013. New Jobs, New Workers, and New Inequalities: Explaining Employers' Roles in Occupational Segregation by Nativity and Race. Social Probl. 60:1-21.

Ievoli C, Macrì MC, 2007. Contesti economici territoriali e domanda e offerta di lavoro in agricoltura, XLIV Congresso SIDEA, 8-10 novembre 2007, Taormina, Italy.

Ievoli C, Macri MC, 2009. Politica Agricola, immigrazione e mercato del lavoro in agricoltura. Agriregionieuropa Anno 5, N. 17.

Il sole 24 ore, 2020. Available from: https://www.ilsole 24ore.com/art/coronavirus-stop-frontiere- raccolti-rischio-1allarme-coldiretti-cia-e-alleanza-cooperative-ADgTejE, and https://www.ilsole24ore.com/art/stagionali-campi-prove-intesa-italia-romania-ma-germania-ha-gia-firmato-ADgIldI and https://www.ilsole24ore.com/art/30mila-richieste-lavorarecampi-profilo-italiani-laureati-e-camerieri-ADcxmUS and https://www.ilsole24ore.com/art/fmi-recessione-globale-20203percento-e-1-italia-pil-calo-9percento-ADWExyJ.

Infomigrants, 2020. Available from: https:/www.infomigrants.n et/en/post/23946/spain-to-hire-foreign-workers-to-cover-agriculture-shortfall

Istituto di servizi per il mercato agricolo ISMEA, 2020. Available from: http://www.ismeamercati.it.

Istituto nazionale di economia agraria INEA, 2009. Annuario dell'agricoltura italiana 2008, Roma, Italy.

Istituto nazionale di economia agraria INEA, 2014. Annuario dell'agricoltura italiana 2013, Roma, Italy.

Istituto nazionale di economia agraria INEA, 2014. Indagine sull'impiego degli immigrati in agricoltura in Italia, a cura di
Cicerchia M., INEA, Roma, Italy.

Gambero rosso, 2020. Available from: https://www.gamberorosso.it/notizie/agricoltura-in-cerca-di-manodopera-stagionale-e-se-la-soluzione-fossero-i-braccianti-irregolari/

Macrì MC, Cardillo C, Vanino S, Perito MA, Coderoni S, 2018. Lavoratori stranieri nell'agricoltura italiana, dove sono e cosa fanno secondo le cifre ufficiali. Agriregionieuropa anno 14 $\mathrm{n}^{\circ} 55$.

Marquez Alcala GM, 2016. Examining the Labor Market Consequences of Endogenous Low-skill Migration with a Market-based Immigration Policy, Agricultural \& Applied Economics Association Annual Meeting, July 31-August 2, Boston, Massachusetts, USA.

Martin PL, 2017. Immigration and Farm Labor: Challenges and Opportunities. Giannini Foundation of Agricultural Economics, University of California.

Mattioni G, Tripodi E, 2018. Il lavoro dipendente in agricoltura in Italia attraverso i dati Inps. Agriregionieuropa anno $14 \mathrm{n}^{\circ} 55$, Dic 2018.

Ministero del Lavoro e delle politiche Sociali MLPS 2019. Piano triennale di contrasto allo sfruttamento lavorativo in agricoltura e al caporalato 2020-2022, Roma, Italy.

Preibisch K, 2010. Pick-Your-Own Labor: Migrant Workers and Flexibility in Canadian Agriculture. Int. Migrat. Rev. 44:404-41.

Preibisch K, 2012. Migrant Workers and Changing Work-place Regimes in Contemporary Agricultural Production in Canada." Int. Sociol. Agric. Food 19:62-82.

Rainews, 2020. Available from: http://www.rainews.it/dl/rainews/ articoli/coldiretti-mancano-braccianti-campi-assaltati-da-animali-a6c313f7-ecbb-443d-ba55-4257362ffd6d.html

Röhm O, Dabbert S, 2003. Integrating agri-environmental programs into regional production models: an extension of positive mathematical programming. Am. J. Agric. Econ. 85:254-65.

Sela E, 2016. Problems of Youth Employment in Albania. Int. J. Human. Social Sci. Invent. 5:4-8.

Terra e vita, 2020. Available from: https://terraevita.edagricole.it/ economia-e-politica-agricola/regolarizzazione-della-manodopera-si-compatta-il-fronte-dei-si/ and https:/terraevita.edagricole.it/featured/lavoro-stagionale-confagricoltura-apre-uncorridoio-verde-con-il-marocco

Zahniser S, Taylor JE, Hertz T, Charlton D, 2018. Farm Labor Markets in the United States and Mexico Pose Challenges for U.S. Agriculture, EIB-201, U.S. Department of Agriculture, Economic Research Service. 